\title{
Gestational Trophoblastic Tumor pM1b TNM Finding v7
}

National Cancer Institute

\section{Source}

National Cancer Institute. Gestational Trophoblastic Tumor pM1b TNM Finding v7. NCI

Thesaurus. Code C89703.

Gestational trophoblastic tumor with all other distant metastasis. (from AJCC 7th Ed.) 